\title{
24
}

\section{THE URBAN CIRCLE OF LIFE OF PEOPLE WITH DISABILITIES}

\author{
Mapping Urban Inconveniences
}

\author{
Katarzyna Ujma-Wasowicz
}

\section{Introduction}

History provides us with evidence that before conscious city planning appeared, cities were shaped by the inhabitants themselves. They have evolved for many hundreds of years, adjusting and adapting the physical environment to urban functions. The effect of these activities, of this process of urban evolution, are also public spaces whose task is to provide the essence of social behaviors.

The way European cities are planned has always reflected not only the prevailing cultural and technological trends but also serious crises. For example, the epidemics of cholera in the 19th century led to the installation of municipal sanitation systems. As an antidote to neutralize respiratory diseases, the modernist movement introduced provisions to ensure greater access to daylight in the apartments and their natural ventilation. In turn, the development of railways and mass production of cars had a huge impact on urban communication systems (van den Berg 2020).

In the above context, when we think about contemporary cities and contemporary urban planning, the progressing development of suburbs (urban sprawl) and housing estates in which the lack of accompanying functions causes the disappearance of social (local) activity is very worrisome from the point of view of the activity of public urban spaces. This activity is moving to shopping centers, which is indicated by their development, and to the Internet. On the other hand, in the 21st century, we are observing an increase in social inequality, segregation, and the decline of the middle class. One can, therefore, speak of a "new crisis of urbanization" (Gzell 2015).

Social activists, who want the city to "bustle with life," raised the alarm that has brought about and continues to bring positive results. Including in Poland, we are observing that in recent years there has come a time of social protests against city planning in a form that does not take into account psychological and sociological aspects, due to which social activity in public spaces has decreased. It should be emphasized that the Covid-19 pandemic has dramatically aggravated this problem. 
The demands that are raised most strongly include, for example, better conditions for pedestrian and bicycle traffic, or better standards for recreation and communal functions. However, above all, efforts should be made to provide fairer conditions for people with special needs to function in public spaces, including people with permanent or temporary disabilities and the elderly and children (Ujma-Wąsowicz and Bielak 2012; Bielak and Ujma-Wąsowicz 2012; Ujma-Wąsowicz 2017). Everyone who has an influence on shaping our cities, from town planners to decision-makers (local, regional, and national), should realize that the battle for high-quality cities and housing estates must be won on a very small scale (Gehl 2011; Pluta 2014). This small scale should be understood as an area in which people experience the surrounding space directly in between buildings and also through the presence of the so-called street furniture.

Another issue is one related to social behaviors. Their intensity translates into whether we are dealing with a "living" city or, on the contrary, with a "dead" or "dying" city. Living cities are those where people interact with each other. Cities like this are always stimulating as they abound in experiences. In lifeless cities, one often encounters a situation of lack of experience and simply boredom. And it does not matter how varied in form or color the buildings or other architectural objects created in them are (Gehl 2011). Therefore, we should strive to ensure that our cities are alive and, thus, that they are accessible in accordance with the principles and goals of universal design, according to which public (at least) space will be accessible to every user, in which there will be not only places without architectural barriers but also intelligent accessibility solutions.

\section{"The Urban Circle of Life" as an Aid in Mapping Urban Accessibility}

Before discussing the titular "urban circle of life," which will be useful in mapping the city's accessibility, it is necessary to not only present the basic tools and methods that are worth using here but also to refer to the issue related to the ideas of a just city and universal design. In the opinion of the author of the study, these two philosophies ought to have a key impact on future city planning.

An equitable city was described by Susan Fainstein in the book entitled The Just City (Fainstein 2010). It is to be characterized by the possibility of various social layers functioning side by side (democracy), equal opportunities in terms of living conditions (equality), and respecting differences in terms of fitness, gender, age, and so on (diversity). In other words, Fainstein strives to promote a thought that when planning and developing cities, one ought to finally move away from the focus being most commonly placed almost exclusively on economic and business indicators and tip the scales toward social justice.

By implementing the above postulate, universal design enters the sphere of spatial planning in a natural way, as a key tool for building cities of the future. It is based on a usercentered design approach, which requires awareness and appreciation of the diverse abilities of people in order to shape flexible, useful, and intuitive spaces for everyone (National Disability Authority USA).

In the 1990s, a team of experts from the University of North Carolina (USA) defined the framework for theory and practice by establishing the 7 Principles of Universal Design. They are as follows: equitable use; flexibility in use; simple and intuitive; perceptible information; tolerance for error; low physical effort; size and space for approach and use. About 20 years later, scientists from the IDeA Center at the University of Buffalo (USA) published 
a list of the principles mentioned above supplemented with the goals of universal design. When developing the above-mentioned goals, the authors (Steinfeld and Maisel 2012) based their content not only on the research conducted but also on the interdisciplinary knowledge of, inter alia, in the field of anthropometry, biomechanics, perception, cognitive processes, safety, health promotion, and social interaction. They specified that by shaping, for example, the space of a city or building, as a result of applying the principles of universal design, we should obtain the following:

1. Body fit - an environment adapted to a wide range of body sizes and capabilities;

2. Comfort - comfortable conditions for the functioning of the human body;

3. Awareness - easy perceptibility of the most important information;

4. Understanding - certainty that the methods of operation and use are intuitive, transparent, and unambiguous for almost every user;

5. Wellness - contribution to health promotion, disease avoidance, and injury prevention;

6. Social integration - certainty that each group will be treated with dignity and respect;

7. Personalization - the ability to choose and express individual preferences;

8. Cultural appropriateness - respect and enhancement of cultural values in the social, economic, and environmental context.

Works related to the acquisition of satisfactory and diverse users of output data as well as project results are often carried out in accordance with the Evidence-Based Design (EBD) research method, a concept derived from the paradigm based on the medicine knowledge (Evidence-Based Medicine). The EBD approach was first defined by Hamilton and Watkins (2009) and involved the conscientious, unambiguous, and reasonable use of the best available knowledge from research and practice in making important design decisions together with an informed client. The authors of the concept mention four levels of evidencebased activities: peer review, unbiased reporting, hypothesis and measurement, and critical interpretation of research. On this basis, among others, "architectural accessibility standards" are also developed, which, for example, in Poland, despite being centrally developed ${ }^{1}$ (commissioned by the Ministry of Investments and Development), are not uniform, as they do not apply and are only a recommendation. Big cities develop their own independent standards (Warsaw, Poznań, Łódź, Gdynia, and other).

The idea of universal design is one issue. However, it is the still existing architectural barriers $^{2}$ for people with physical, sensory, or intellectual disabilities that are a key problem for the accessibility of public spaces in many medium-sized European cities. In this regard, urban audits is the key word for the changes undertaken.

When trying to verify scientifically whether a given space meets the criteria of architectural accessibility, two combined methods should be used, namely, a research walk and a qualitative research method in architecture and urban planning called Post-occupancy Evaluation (Fross 2012; Niezabitowska 2014). POE is a method of assessing the quality of the built environment during its use with the participation of customers and users. This method of examining buildings and spaces in between them covers three basic areas of issues: technical quality (e.g., technical condition, maintenance, technical safety), functional quality (including organizational and ergonomic), and behavioral quality (e.g., the impact of the organization of the place on behavior, spatial orientation, safety, and the sense of aesthetics). In a group of behavioral issues, the topic of sensory perception of space through smell, sound, touch, and others is also undertaken. 
This research line of reasoning should be placed at the heart of the problem of barriers to accessibility, by realizing where and why they arise. Of course, town planning audits are nothing new. However, as is usual with carrying out such audits, the "devil is in the details." Here a method is proposed that can be an alternative approach to the subject.

Most people, including designers, perceive the issue of architectural barriers through the prism of a given place; for example, there is no ramp or elevator, a parking space, or an adapted toilet. The lack of these architectural and urban elements is, however, only a fragment of a much wider optics.

In order to understand the many dependencies that determine whether public spaces are accessible spaces for people with disabilities, it suffices to look at the scheme called the "urban circle of life" which can be found in the Figure 24.1. In order to take full advantage of public spaces, it is necessary to reach them. A disabled person starts their journey to the city, from their place of residence, which in most cases is adapted to the special needs of the disabled tenant. For this person, the first moment where a barrier may be encountered is leaving the apartment, the next one is exiting the house or residential building, then reaching the car or public transport stop, getting to the destination, parking the car or getting off at the desired bus stop, then walking from the parking lot or bus stop to their destination. Finally, entering the building, moving around it. Returning home takes place in a similar fashion.

Identification of barriers to urban accessibility, in accordance with the need of a person with permanent or temporary disabilities to move about, can be done using the method of mapping them and on the basis of a list used for auditing. However, for the accessibility

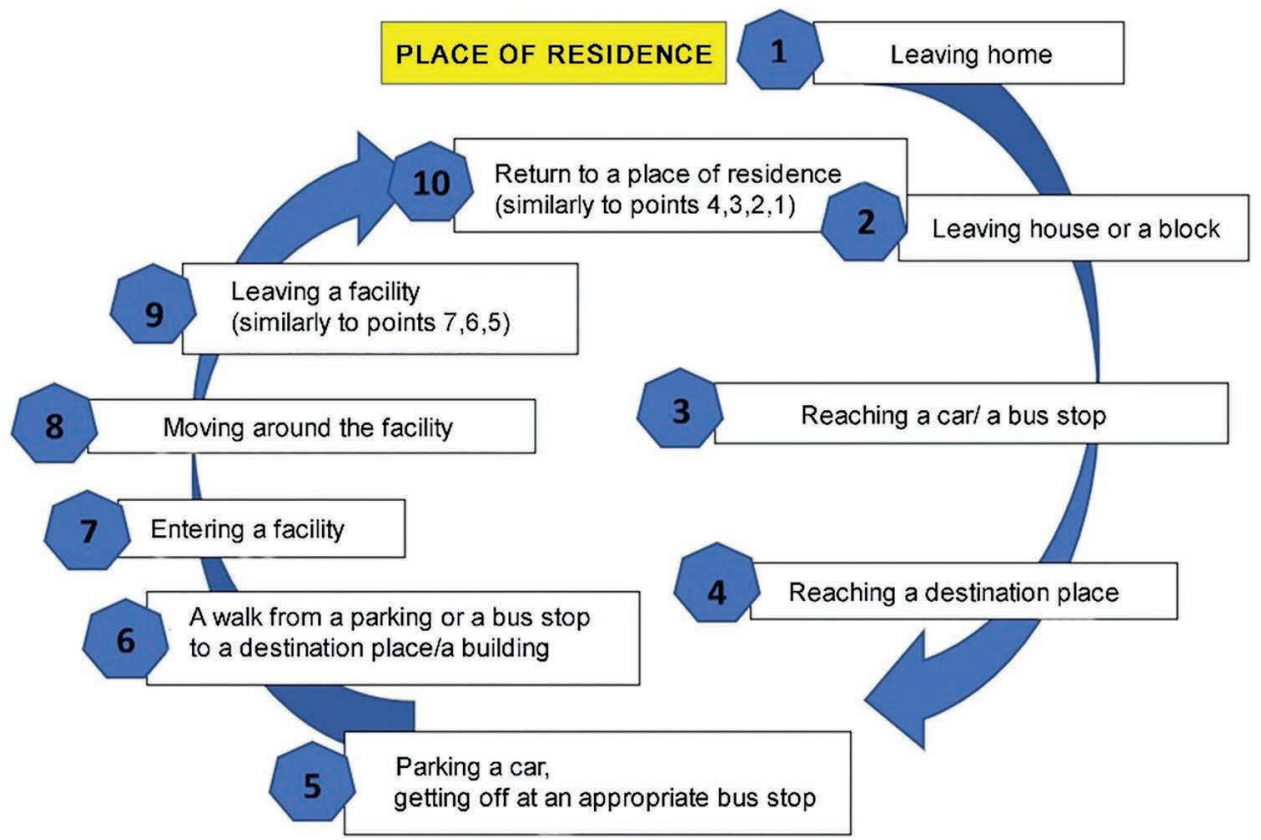

FIGURE 24.1 The urban circle of life.

Source: own study. 
audit to be credible, the person conducting it should have empathetic features; that is, they must demonstrate an understanding of the limitations of people with disabilities, their need to choose destinations and paths by means of which they would like to get to them, and, finally, what dangers these people may be exposed to in the public space.

One more important issue should be raised in this context. It very often happens that when designing a given urban or architectural space, the designer thinks, in best faith, about ensuring accessibility to each group independently: to people in wheelchairs, to the blind, to the deaf, and others. However, it should be realized that some seemingly most obvious concepts are not solutions for everyone; for example, a lowered curb for a wheelchair user is a big risk for a blind person (they do not know the moment they are on the street); modern and aesthetic touch panels in elevators are completely unsuitable for the blind; on the one hand, repeated voice information in public transport is crucial for the orientation of people who do not know the route and the blind, but, on the other hand, it can be irritating and annoying (e.g., for a bus/tram driver), and there are many other such incompatible ways to avoid inconvenience. Therefore, in order to gain knowledge in the above scope, the audit should be carried out with the simultaneous participation of people with various disabilities, for example, people using manual and electric wheelchairs, a person who is blind from birth and thus already blind in adulthood, a deaf and hard-of-hearing person, and so on. It is extremely important for the elimination of spatial barriers in accordance with the principles and goals of universal design.

The mapping method proposed starts with the disabled person specifying a path from their home to the place as selected by them and following their public route in the most detailed way. The same path (especially in public spaces) should be followed by people with other illnesses or those moving with the use of other equipment/devices. In this way, the potential conflicts mentioned above will be detected.

The author's research to date (carried out, of course, with the team) was qualitative in nature. It highlighted the aforementioned accessibility problems and the need to solve them among persons concerned. Such research conclusions were drawn, among others, during a training course initiated by the author and financed by the Marshal's Office of the Silesian Province (Poland), held in October 2019 for employees of the public sector (the City Hall, the Municipal Social Assistance Center, the County Family Assistance Center, and others) in order to raise the level of awareness and knowledge of these employees about the real limitations and needs of disabled people with respect to movement and handling of various matters. This task was carried out in cooperation with the authorities of the City of Dąbrowa Górnicza (Poland). The workshops were conducted for two days. On the first day, field classes were held with the participation of the officials, invited disabled tutors (at least two, with various disabilities), and people elected to write down comments; each ablebodied participant could choose one of the ways to impersonate a disabled person: move in a wheelchair, put on goggles that impair vision, or put on an old age suit. The participants were divided into three groups (approximately 10 people in a group), each of which traveled a different, previously designated, route around the city: on foot and by bus or train. On the second day, there were lectures raising the audience's awareness and discussions summarizing the first day devoted to research walks.

The author together with a team of academic teachers and tutors conducted similar research with students of the Faculty of Architecture of the Silesian University of Technology in Gliwice in February 2019 and 2020 (Poland). Figures 24.2 and 24.3 show these activities. 


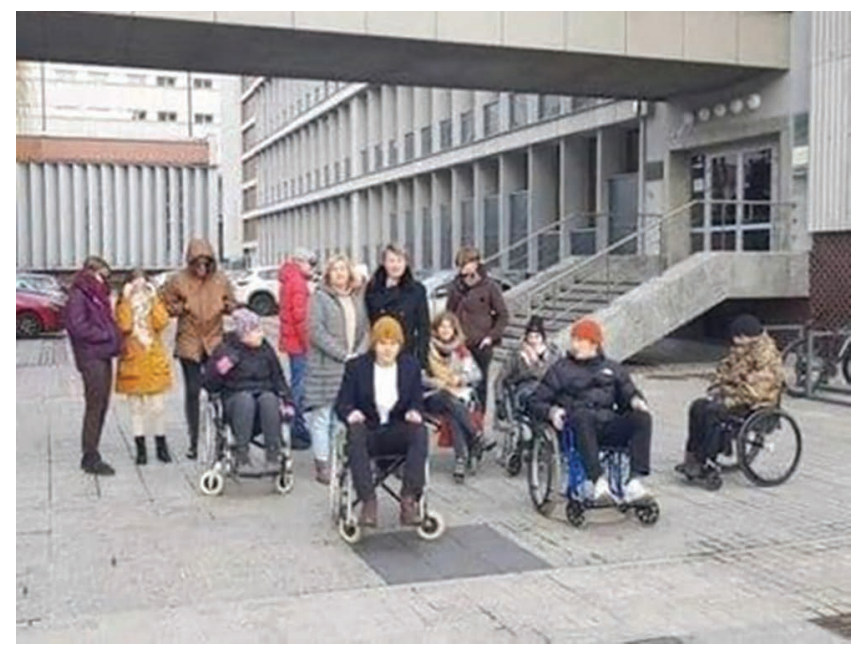

FIGURE 24.2 The students of the Faculty of Architecture of the Silesian University of Technology in front of their home faculty accompanied by Dean Fross and the author.

Source: K. Ujma-Wąsowicz, 2019.

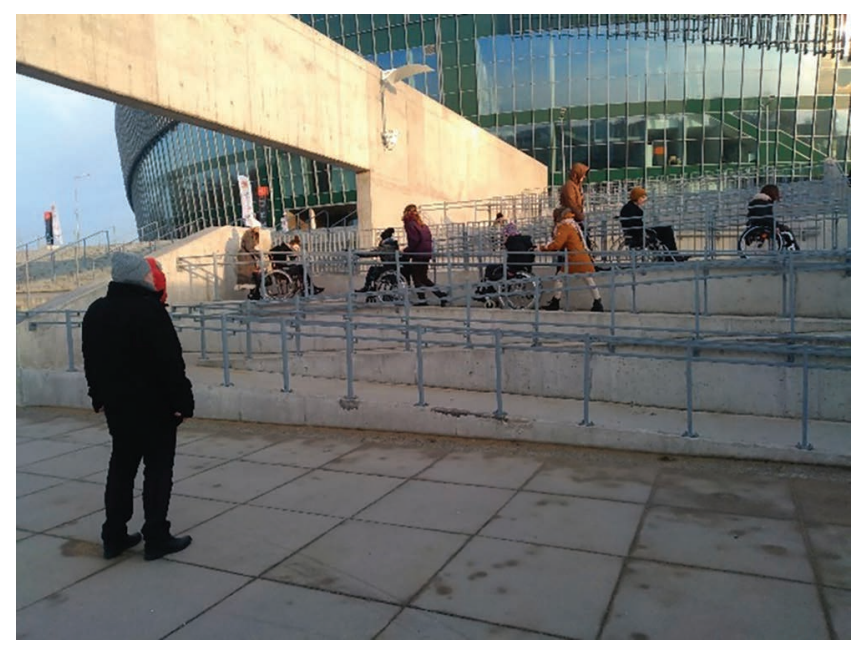

FIGURE 24.3 The students of the Faculty of Architecture of the Silesian University of Technology during a research walk.

Source: K. Ujma-Wąsowicz, 2020.

When undertaking ongoing in-between buildings audit activities, it is worthwhile, in addition to qualitative research, to conduct quantitative research, for example, showing how many places on the audited path are not adapted to a given disability at all and in how many places there are obvious conflicts between disabilities. This should give food for thought to the authorities (persons/institutions) deciding about the financing of possible changes, if it turns out that, most audited points on the path are not adjusted. Certainly, in addition to 
the order for changes which are brought about by, for example, the Act on Ensuring Accessibility to People with Special Needs ${ }^{3}$ (here only in public buildings), in force in Poland since July 2019, this should be a convincing argument for improving the quality of open, in-between buildings and public spaces.

\section{Post-Pandemic and Universal Design}

The changes related to the pandemic have sparked many debates about the future. Also the one that tries to determine how cities can be built for present and future generations, and perhaps more importantly, how they can better respond to current and future crises.

In recent years, digitization and ubiquitous access to data have transformed the way in which we move around cities and how communities mobilize and advocate for potential change. Devices such as cellphones (around 9.8 billion), satellites $(2,200)$, and other digital sensors (over 25 billion) still provide us with abundant amounts of data on human traffic, the environment, economic trends, and more. Owing to this, we are learning how significantly people have changed their behavior in response to the Covid-19 pandemic and that the effects of these changes do not affect everyone equally (Mackres 2020).

However, when life returns to normal, planners will have to take up new challenges related to the organization of cities and, thus, the organization of their inhabitants' lives.

Thus, the question of how, as designers, we should/could steer our thinking about the space shaped by us after the pandemic remains open. What new information resources should we explore both in terms of human knowledge and in terms of the environment and technology?

An interesting perspective on this issue can be found in the article by V. Lanteigne and M-Y M. Oram from August 2020 entitled Universal Design: A tool for creating equitable spaces after COVID-19. The authors present in it examples of applications of the idea of universal design, which will steer the design strategies in the future:

- Neurodiversity - the essence of design here is to adapt the environment for people with autism spectrum disorders (ASD), attention deficit hyperactivity disorder (ADHD), or learning difficulties. Universal design encourages one to dwell on color, pattern, texture, sound, and light in order to create more equitable spatial experiences.

- Mental Health and Well-being - the effects of COVID-19 have contributed to an increase in anxiety and depression, thus elevating the importance of health and wellness upon returning to work. To achieve a positive impact on well-being, universal design promotes mental health strategies, including through active (with the users) design of the workplace (ergonomic elements are emphasized).

- Technologies - technological progress will be an important mechanism to support new ways to use our spaces, including automated sensors, lighting, computer software, applications, and more.

- Transport - as mobility restrictions will slowly be in decline, public transport health and safety measures will not ensure complete safety. Hence, the bicycle should continue to be popularized as an available and attractive alternative in urban spaces for everyone (Lanteigne and Oram 2020).

Certainly driverless taxis, that is, autonomous cars, also seem to be an attractive alternative. 


\section{Summary}

The character of the city, including its quality and beauty, is assessed by staying in and exploring urban public spaces. If we undertake the issue of the way in which public space is shaped and functions, it certainly depends on many interdependent factors such as the social system of values, local conditions, quality of law, as well as the efficiency of the market activity and the efficiency of local authorities and other public institutions. It is also obvious that new public space solutions are often part of long-term development plans of a city or its parts, influencing the transformation processes of its entire spatial structure.

Strategic decisions, based, for example, on the problems of public space accessibility as discussed briefly are just as important as the detailed ones, involving the urban detail. Therefore, a holistic approach to planning is necessary, where one of its elements should be audit of public spaces accessibility. The "urban circle of life" can be a useful tool for such inspection.

\section{Acknowledgments}

I would like to extend my thanks to the following persons and institutions, owing to which the undertaking under the name "Our Cities Are (Not) Limping" took place:

- The Marshal's Office of the Silesian Province - for consent to conduct the training and financing it https://rpo.slaskie.pl/czytaj/nasze_miasta_nie_kuleja_dostepnosc_ szkolenie_092619

- The Silesian Association of Communes and Counties - for help in organizing the training https://silesia.org.pl/aktualnosci/nasze-miasta-niekuleja,291

- The City Hall of Dąbrowa Górnicza - for commitment and assistance in organizing the training https://www.dabrowa-gornicza.pl/aktualnosci/nasze-miasta-niekuleja/

- The Society of Polish Town Planners Silesian Branch, which the author represents, for the organization of the undertakinghttp://www.tup.org.pl/index.php?option=com_content $\&$ view $=$ article $\& i d=1826 \% 3$ Anasze-miasta-niekulej\&catid=138\%3Aaktualnoci\&Itemid= $215 \&$ lang $=\mathrm{pl}$

Professor Fross, Dean of the Faculty of Architecture, and Lech Wojtas, PhD - for involvement in the organization of classes for first-year students of the Faculty of Architecture of the Silesian University of Technology (2019, 2020) https://www.polsl.pl/Wydzialy/RAr/Lists/Aktualn osciWydzialuArchitektury/PokazWiadomosc.aspx? WebPartTitle=ListaWiadomosci\&Page $=20 \&$ WebPartTitle2 $=$ Wiadomosc \&Filter1Field2=Identy fikator\&Filter1Value2 $=1271$

The disabled friends invited by the author to cooperate with her upon many undertakings organized by her: Agnieszka Filipkowska, PhD, Ada Kempka, Sławomir Cywka, Mariusz Miszuda, Jan Szuster, and others.

\section{Notes}

1 Building accessibility standards for people with disabilities file://C:/Users/admin/ Downloads/STANDARDY_DOST\%C4\%98PNO\%C5\%9ACI_BUDYNK\%C3\%93W.pdf

2 In Poland, this problem was presented in the Report of the Supreme Audit Office in 2018 file://C:/Users/admin/Desktop/DOST\%C4\%98PNO\%C5\%9A\%C4\%86/NIK_kontrola\%20 dost $\%$ C $4 \% 99$ pno\%C5\%9Bci.pdf 
3 Act of July 19, 2019 https://www.funduszeeuropejskie.gov.pl/media/82728/dziennikustaw_19 lipca2019.pdf

\section{Bibliography}

Bielak M. and Ujma-Wąsowicz K. 2012. Metodologiczne aspekty badań nad kształtowaniem środowiska zbudowanego dla użytkowników grupy wiekowej 50+. In Czasopismo Techniczne Architektura 1-A/1: 73-80

Fainstein S. 2010. The Just City. New York: Cornell University Press

Fross K. 2012. Badania jakościowe w projektowaniu architektonicznym na wybranych przykładach. Gliwice: Wydawnictwo Politechniki Śląskiej

Gehl J. 2011. Life between buildings: Using Public Space. Sixth Edition. Island Press

Gzell S. 2015. Wykłady o wspótczesnej urbanistyce. Lectures on Contemporary Town Planning. Warszawa: Oficyna wydawnicza Politechniki Warszawskiej

Hamilton D.K., Watkins D.H. 2009. Evidence-based design for multiple building types. John Wiley \& Sons

Niezabitowska E. 2014 Metody i techniki badawcze w architekturze. Gliwice: Wydawnictwo Politechniki Śląskiej

Pluta K. 2014. Przestrzenie publiczne miast europejskich. Projektowanie urbanistyczne. Warszawa: Oficyna wydawnicza Politechniki Warszawskiej

Ujma-Wąsowicz K. 2017. Czy współczesne miasta są dla ludzi? Ergonomiczne aspekty kształtowania przestrzeni zurbanizowanej. In Ergonomia w architekturze i urbanistyce. Kierunki badań w 2017 roku. ed. J. Charytonowicz 35-46. Wrocław: Wydawnictwo Polskiego Towarzystwa Ergonomicznego PTErg. Oddział we Wrocławiu

Ujma-Wąsowicz K. and Bielak M. 2012. Urbanistyczne aspekty kształtowania środowiska zbudowanego dla użytkowników grupy wiekowej 50+ In Czasopismo Techniczne Architektura 1-A/1: 269-276

\section{Online Documents}

Act of 19 July 2019 o zapewnieniu dostępności osobom ze szczególnymi potrzebami, Dziennik Ustaw poz. 1696

van den Berg R. 2020 How Will COVID-19 Affect Urban Planning? https://thecityfix.com/blog/willcovid-19-affect-urban-planning-rogier-van-den-berg/ [access: 10.01.2020]

https://www.funduszeeuropejskie.gov.pl/media/82728/dziennikustaw_19lipca2019.pdf [access: 10.01.2020]

Mackres E. 2020 Insights from Big Data on How COVID-19 Is Changing Society https://thecityfix.com/ blog/insights-big-data-covid-19-changing-society-eric-mackres/ [access: 10.01.2020]

Man Oram M-Y and Lanteigne V. 2020 Universal Design: A tool for creating equitable spaces after COVID19 https://resources.wellcertified.com/articles/universal-design-a-tool-for-creating-equitablespaces-after-covid-19/ [access: 10.01.2020]

Steinfeld and Maisel 2012. What Is Universal Design? Center for Inclusive Design and Environmental Access, University of Buffalo http://idea.ap.buffalo.edu/about/universal-design/ [access: 10.01.2020]

Raport Najwyższej Izby Kontroli z dnia 15.10.2018 r. Dostępność przestrzeni publicznej dla osób starszych $i$ niepetnosprawnych nr 111/2018/P/17/094/LPO file://C:/Users/admin/Desktop/DOS T\%C4\%98PNO\%C5\%9A\%C4\%86/NIK_kontrola\%20dost\%C4\%99pno\%C5\%9Bci.pdf [access: 20.07.2020]

Standardy dostępności budynków dla osób z niepełnosprawnościami file:///C:/Users/ admin/Downloads/STANDARDY_DOST\%C4\%98PNO\%C5\%9ACI_BUDYNK\%C3\%93W. pdf [access: 20.07.2020]

What Is Universal Design? National Disability Authority. http://universaldesign.ie/What-is-UniversalDesign/ [access: 10.01.2020] 